\title{
Adipose Stromal/Stem Cell-Derived Extracellular Vesicles: Potential Next-Generation Anti-Obesity Agents
}

\author{
Mariachiara Zuccarini ${ }^{1,2,+}$, Patricia Giuliani ${ }^{1,2,+}$, Valentina Di Liberto ${ }^{3} \mathbb{D}$, Monica Frinchi ${ }^{3}$, Francesco Caciagli ${ }^{2}$, \\ Vanni Caruso ${ }^{4}(\mathbb{D})$, Renata Ciccarelli ${ }^{1,2,5, *(\mathbb{D})}$, Giuseppa Mudò ${ }^{3}$ (D) and Patrizia Di Iorio ${ }^{1,2}$ \\ 1 Department of Medical, Oral and Biotechnological Sciences, University of Chieti-Pescara, Via dei Vestini 29, \\ 66100 Chieti, Italy; mariachiara.zuccarini@unich.it (M.Z.); patricia.giuliani@unich.it (P.G.); \\ patrizia.diiorio@unich.it (P.D.I.) \\ 2 Center for Advanced Studies and Technologies (CAST), University of Chieti-Pescara, Via L. Polacchi, \\ 66100 Chieti, Italy; f.caciagli@unich.it \\ 3 Department of Biomedicine, Neuroscience and Advanced Diagnostic, University of Palermo, \\ 90128 Palermo, Italy; valentina.diliberto@unipa.it (V.D.L.); monica.frinchi@unipa.it (M.F.); \\ giuseppa.mudo@unipa.it (G.M.) \\ 4 School of Pharmacy and Pharmacology, University of Tasmania, Hobart 7001, Australia; \\ vanni.caruso@utas.edu.au \\ 5 Stem TeCh Group, Center for Advanced Studies and Technologies (CAST), Via L. Polacchi, 66100 Chieti, Italy \\ * Correspondence: renata.ciccarelli@unich.it \\ + These authors contributed equally to this work.
}

Citation: Zuccarini, M.; Giuliani, P.; Di Liberto, V.; Frinchi, M.; Caciagli, F.; Caruso, V.; Ciccarelli, R.; Mudò, G.; Di Iorio, P. Adipose Stromal/Stem Cell-Derived Extracellular Vesicles: Potential Next-Generation Anti-Obesity Agents. Int. J. Mol. Sci. 2022, 23, 1543. https://doi.org/ $10.3390 /$ ijms 23031543

Academic Editors: Heba Abdelrazik, Elena De Falco, Alessandra Pelagalli and Sara Perteghella

Received: 18 November 2021

Accepted: 26 January 2022

Published: 28 January 2022

Publisher's Note: MDPI stays neutral with regard to jurisdictional claims in published maps and institutional affiliations.

Copyright: (C) 2022 by the authors. Licensee MDPI, Basel, Switzerland. This article is an open access article distributed under the terms and conditions of the Creative Commons Attribution (CC BY) license (https:// creativecommons.org/licenses/by/ $4.0 /)$.
Abstract: Over the last decade, several compounds have been identified for the treatment of obesity. However, due to the complexity of the disease, many pharmacological interventions have raised concerns about their efficacy and safety. Therefore, it is important to discover new factors involved in the induction/progression of obesity. Adipose stromal/stem cells (ASCs), which are mostly isolated from subcutaneous adipose tissue, are the primary cells contributing to the expansion of fat mass Like other cells, ASCs release nanoparticles known as extracellular vesicles (EVs), which are being actively studied for their potential applications in a variety of diseases. Here, we focused on the importance of the contribution of ASC-derived EVs in the regulation of metabolic processes. In addition, we outlined the advantages/disadvantages of the use of EVs as potential next-generation anti-obesity agents.

Keywords: obesity; metabolic disease/syndrome; extracellular vesicles; adipose tissue; adipose stromal/stem cells (ASCs)

\section{Introduction}

Over the past two decades, obesity rates have risen dramatically in the developed and developing world [1,2], and the consequences of obesity represent a major public health concern [3].

Obesity is a complex and multifactorial medical condition resulting from a chronic imbalance between energy intake and energy expenditure, and characterized by increased adipose tissue stores [4]. Genetic and epigenetic signatures as well as behavioral and social factors contribute to the obesity epidemic [4]. Moreover, comorbidities associated with obesity, including cardiovascular and chronic kidney diseases, diabetes and some cancers greatly increase mortality rates in obese patients as well as public healthcare costs [5-7].

Health benefits in obesity result from weight loss. Pharmacotherapy is suggested as an adjunct to a reduced-calorie diet and increased physical activity for long-term weight management [8]. However, insufficient efficacy and concerns about drug safety for the long-term use of weight-loss agents quite often coincide with the termination of drug treatment and weight regain for the patient [8]. 
A large number of scientific investigations have focused on the role of adipose tissue (AT) in the pathophysiology of obesity in an attempt to identify new druggable targets. Several studies have highlighted the implications of multipotent mesenchymal stromal cells (MSCs) in the proliferation of the adipose mass in obesity [9]. MSCs are known as adipose stromal/stem cells (ASCs) [10] and are recognized as the primary source contributing to fat mass enlargement (reviewed in [11]). The metabolic activity of these cells is linked to the release of factors which are transported by different types of extracellular vesicles (EVs), also known as "nanoparticles". Alterations of the physiological function of EVs have been linked to several human diseases, including those related to metabolic dysfunctions as well as blood and liver disorders (reviewed in [12]). For these reasons, the contribution of ASCderived EVs in obesity could become a major focus in future drug discovery programmes.

Therefore, here, we reviewed recent literature on the role of EVs in the metabolism of AT, highlighting their specific contribution in adipogenesis and metabolic homeostasis. Additionally, we revised how the properties of ASC-derived EVs could be usefully exploited for potential therapeutic applications in obesity and related comorbidities.

\section{AT: A Complex Tissue Compartment}

The AT, widespread throughout the body, is a tissue of mesenchymal origin and it is usually divided into brown AT (BAT) and white AT (WAT).

BAT is known to be involved in the regulation of body temperature. Rodents and humans possess two types of thermogenic adipocytes arising from distinct lineages: the classical brown adipocytes and the so-called beige or brite cells that are released by the WAT to increase the body's thermogenic capacity [13]. However, additional studies have demonstrated that BAT interacts with some peripheral tissues, secreting molecules capable of controlling their functions as well as body energy homeostasis [14].

In the human, WAT mainly acts as energy reservoir, storing fatty acids (FAs), which are released during fasting periods to supply energy to the organism. WAT is composed of subcutaneous AT (SAT) and visceral AT (VAT). Although morphologically similar, SAT and VAT show distinct characteristics with regard to metabolic homeostasis and dysfunction. While VAT expansion is associated with an increased risk of metabolic and/or cardiovascular diseases, as well as mortality, the expansion of SAT improves insulin sensitivity and reduces metabolic complications [15].

Human WAT is a heterogeneous tissue composed of $50 \%$ lipid-filled cells called adipocytes, which are involved in metabolic functions including lipogenesis, lipolysis and FA oxidation. However, these cells perform additional activities, behaving as immune and endocrine cells. In fact, they are able to release anti- and pro-inflammatory cytokines, as well as a large number of adipokines (reviewed in $[15,16]$ ), which modulate metabolism and the inflammation developed in obesity, thus playing a crucial role in the pathophysiology of this disorder. The remaining $50 \%$ is represented by non-adipocyte cells, which include endothelial and various types of immune cells, such as macrophages, eosinophils and mast cells. Collectively, this anatomical compartment of AT is referred to as the stromal vascular fraction (SVF), which is highly involved in the maintenance of AT homeostasis. A small but very relevant portion of this fraction is represented by ASCs. These cells possess multipotency and ability to give rise to osteoblastic, chondrocytic and adipocytic lineages [17]. Moreover, ASCs, both isolated from SVF and grown in culture, express mesenchymal surface markers in common with those of bone marrow-derived MSCs (BMMSCs) such as CD90, CD73, CD105 and CD44, while they are negative for the hematopoietic marker CD45 (leukocyte common antigen) and CD31 (PECAM-1), a marker for endothelial cells also found in platelets and leukocytes. However, ASCs differ from BM-MSCs, being positive for CD36 (GPIIIb) and negative for CD106 (V-CAM-1) [17].

\section{Features of ASCs in Healthy and Dysmetabolic Conditions}

In an elegant study, Ong and colleagues identified several potential depot-specific markers by investigating over 240 cell-surface markers through high-content image screen- 
ing. This study suggested that CD10 has a predominant expression in SAT-ASCs and CD200 in VAT-ASCs of both humans and mice. Additionally, the authors demonstrated that SAT-ASCs with high CD10 expression differentiated better towards an adipogenic phenotype than their low CD10 expression counterparts. In contrast, low-CD200 VAT-ASCs differentiated better than the same cells with high CD200 expression [18].

However, in the obese phenotype, there are further biological/functional differences regarding the ASCs [19]. In fact, the ASCs isolated from the SAT of obese subjects show a much higher proliferation rate and adipogenic differentiation capacity than those derived from VAT [20,21], while VAT-ASCs have upregulated clusters of genes related to lipid biosynthesis and metabolism [22]. Considering the limited ability of VAT-ASCs to differentiate into new adipocytes, this could partly explain the hypertrophy of existing adipocytes as a response to fat accumulation in obesity [23]. Conversely, the increased differentiation capacity of SAT-ASCs induces the formation of new adipocytes (hyperplasia) with smaller lipid vacuoles (reviewed in [24]), the number of which is approximately double in obese compared with non-obese subjects [25]. There are some exceptions, such as those shown by the ASCs present in mediastinal fat, which are considered to belong to the VAT. These cells express, in addition to putative mesenchymal surface markers, BAT-specific genes, with the capacity of differentiating into metabolically active brown adipocytes, which could contrast with fat accumulation in VAT [26].

SAT- or VAT-ASCs behave differently in obesity: a prevalent expansion of VAT, mostly due to ASC hypertrophy, is correlated with a greater susceptibility to metabolic disorders. However, this correlation is not observed in obese people with expanded SAT-ASCs, in whom the metabolic parameters are closer to the normal range, as reviewed in [11] and summarized in Figure 1. These subjects are indicated as "metabolically healthy obese". However, most of them tend to lose their status over time, and obesity confers a higher risk of developing metabolic syndrome risk factors [27].

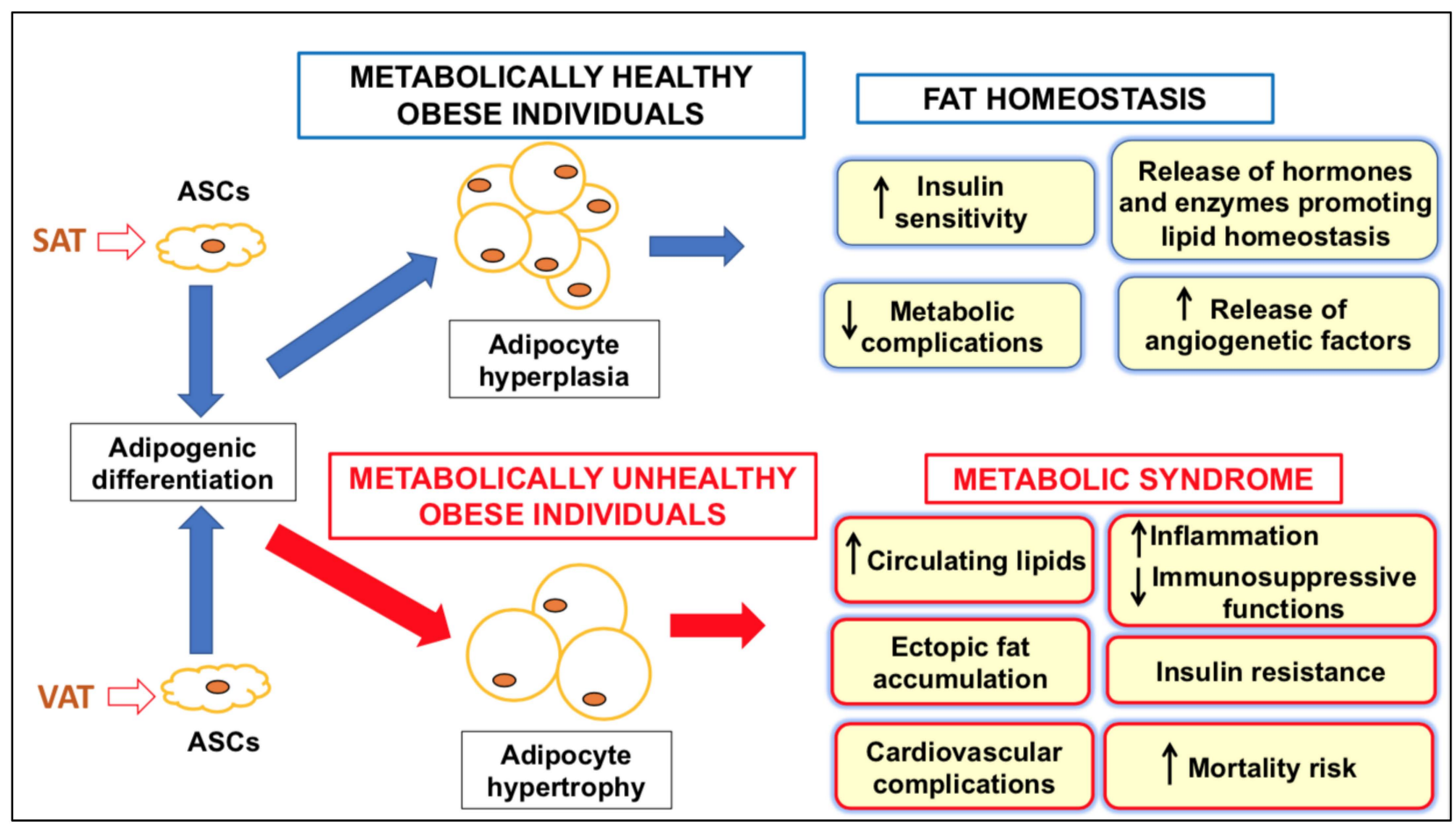

Figure 1. Schematic representation of the events occurring in metabolically healthy or unhealthy obese subjects. SAT-ASCs have the main function of regulating fat homeostasis in the AT, while VAT-ASC hypertrophy contributes to the onset of metabolic syndrome. Abbreviations: ASCs, adipose stromal/stem cells; SAT, subcutaneous adipose tissue; VAT, visceral adipose tissue. 
ASCs from the two adipose areas also differ in the expression/release of hormones linked to fat homeostasis, such as adipokines/lipokines, or the lipolysis/triglyceride synthesis rate $[19,24]$. Additionally, SAT-derived ASCs are mostly able to secrete angiogenic factors, mainly under hypoxic conditions, which allow cell survival in an ischemic environment. In vitro studies suggest that while these cells derived from healthy subjects act as a reservoir of growth factors necessary for promoting angiogenesis, this ability is impaired in ASCs derived from obese individuals [28].

ASCs usually exhibit immunosuppressive functions similar to most MSCs in healthy subjects; in contrast, in the AT of obese subjects, this function is compromised [29]. In agreement with these results, Lefevre et al. [30] showed that ASC depots exhibit specific differences in mice fed a high-fat diet so that low-grade inflammation develops with obesity in VAT, while it is delayed in SAT. In turn, the pro-inflammatory environment associated with metabolic disease influences ASC proliferation and differentiation potential. Thus, ASCs from obese animals, corresponding to an early stage of obesity, show an increase in senescence as well as in adipogenic potential compared with ASCs from lean animals. Conversely, the ASCs obtained from the SAT of morbidly obese patients, who represent a late stage in the obesity process, exhibited a lower capacity for proliferation and adipogenic differentiation than ASCs from non-obese subjects (reviewed in [28]). Altogether, these results highlight the heterogeneity of ASCs and indicate that the progression towards metabolic impairment can heavily affect all functions of ASCs [31,32]. These aspects are crucial factors for the use of ASCs in regenerative medicine, as pointed out in Section 5.

Recent investigations have suggested that ASCs from healthy or obese subjects can also be distinguished according to the biochemical proprieties of their EVs. In the next section, we report the most recent advancements in this regard.

\section{Characterization of EVs Obtained from ASCs}

EVs are nanoparticles that are gaining increasing interest as innovative tools in medicine, with a wide range of clinical applications in disease diagnosis, prognosis and therapy, as well as in tissue repair/regeneration [33]. They arise from the lipid bilayer of the membrane and are secreted from virtually all cells into biological fluids. EVs are heterogeneous in size, membrane composition and content, consisting of DNA, RNA, lipids and proteins. All these features largely represent the tissue or cell of origin [34]. Three main types of EVs have been characterized and labeled as exosomes, microvesicles and apoptotic bodies. The exosomes (sizes from 30 to $200 \mathrm{~nm}$ ) are formed intracellularly and secreted after the fusion of multivesicular bodies with the cell surface; the microvesicles (200-1000 nm) are formed by the outward budding of the plasma membrane, while apoptotic bodies (larger than $1000 \mathrm{~nm}$ ) are released during the late stage of apoptosis and mainly contain nuclear material from dying cells. There is also an additional subtype reported as shed midbody remnants, which are released during cytokinesis (200-600 nm) [35]. EVs have been identified as vital components in intercellular communication and being capable of transferring information to nearby or distant cells, which affects cells' physiological and pathological functions [36,37].

In relation to AT, recent investigations have indicated that EVs released from WAT cells play a major role in maintaining metabolic homeostasis or modulating various metabolic disorders [12]. In addition, other studies suggested that BAT is also capable of releasing EVs, which could be used as therapeutic agents for obesity and related diseases [38]. Unfortunately, the availability and accessibility of these important AT depots are limited, so that the potential translational use of these ASCs and related EVs in clinical practice is reduced. Therefore, here, we focused on the content and activity of EVs, mainly exosomes, isolated from WAT-derived ASCs.

Standardized methodological approaches to isolate and characterize EVs from adipose cells as well as from any other sources are still lacking [39]. Taking this limit into account, a variety of nucleic acids and proteins have been identified in ASC-derived EVs as important mediators of the paracrine function of ASCs [40]. 
MicroRNAs (miRNAs) can be isolated from rat [41] and porcine ASC-derived EVs [42]. The miRNAs are small single-stranded non-coding RNA molecules (containing about 22 nucleotides) present in all living organisms that function in RNA silencing and posttranscriptional regulation of gene expression. In humans, the literature shows that the size, but not the number, of ASC-derived EVs from obese individuals is smaller than those from lean individuals [43]. Similar data have been obtained in swine [44]. Scientific evidence has indicated that obesity can alter the miRNA content of ASC-derived EVs as well as the ability of these nanoparticles to modulate important injury pathways in the recipient cells $[43,45]$. Data from human subjects showed that eight miRNAs were upregulated and 75 miRNAs were downregulated in obese EVs vs. lean EVs. While upregulated miRNAs from ASC-derived EVs of obese subjects were involved in the modulation of nuclear factor $\mathrm{kB}(\mathrm{NF}-\mathrm{kB})$ and mitogen-activated protein kinase (MAPK) signals, as well as in cytoskeleton organization and apoptosis, those downregulated in the same EVs were implicated in the cell cycle and angiogenesis, and in modulating other signals such as those transduced by the Wnt and MAPK molecular pathways. The authors suggested that treating damaged human proximal tubular epithelial cells (HK2 cells) with ASC-derived EVs obtained from obese individuals were less effective at reducing inflammatory reaction and apoptosis than the corresponding EVs isolated from ASCs of lean subjects [43]. Similarly, intrarenal delivery of EVs obtained from ASCs of obese swine was unable to preserve the microcirculation and improve function in pigs with renovascular disease [45]. Collectively, these findings indicate that obesity might increase the content of these miRNAs in human ASC-derived EVs, which, in turn, might promote pro-inflammatory signals and apoptotic death, while reducing those involved in cell proliferation and angiogenetic processes.

Other studies have demonstrated that ASCs release exosomes that could influence proliferation and regeneration pathways in AT [46-49]. Among these articles, a recent review reported the presence of 591 proteins together with that of 604 miRNAs in EVs derived from human ASCs. The most important molecular function of these proteins is related to signaling receptor binding. The authors of this review also highlighted the biological processes in which these proteins are involved, which include development processes, cell adhesion, immune system processes, response to stimuli and locomotion, among others. As for the molecular functions of the miRNAs present in ASC-derived EVs, the authors substantially confirmed the involvement of these nanoparticles in the biological processes reported above [49].

\section{Experimental Use of ASC-Derived EVs in Pathological Conditions}

The content of ASC-derived EVs can be modified by various cell culture conditions, such as proinflammatory stimuli as well as oxidative stress or hypoxia, or by their transfection with lentiviral particles (reviewed in [49]), confirming their role in antigenic/antiinflammatory/immunosuppressive functions [50]. Hence, EVs from ASCs are also currently actively studied for their possible therapeutic uses in several pathological conditions ranging from neurodegenerative to cardiovascular and respiratory diseases, as well as for regeneration of skeletal tissue or wound healing (Table 1) [47,49].

Special attention is paid to the angiogenic effects of ASC-derived EVs [51]. Proangiogenic effects could be ascribed to the presence of some miRNAs including miR-31, miR-125 and miR-126. Specifically, miR-31 suppresses the activation of the factor FIH-1 (factor-inhibiting hypoxia-inducible factor 1), thus favoring the activation of hypoxiainducible factor 1 (HIF-1), a key regulator that mediates the cell response to hypoxia and angiogenesis. miR-125 inhibits the expression of the angiogenic inhibitor delta-like 4 , and miR-126 maintains a proliferative reserve in endothelial cells through suppression of the Notch1 inhibitor delta-like 1 homolog (Dlk1) [52]. 
Table 1. Some of the experimental uses of EVs derived from ASCs for clinic applications.

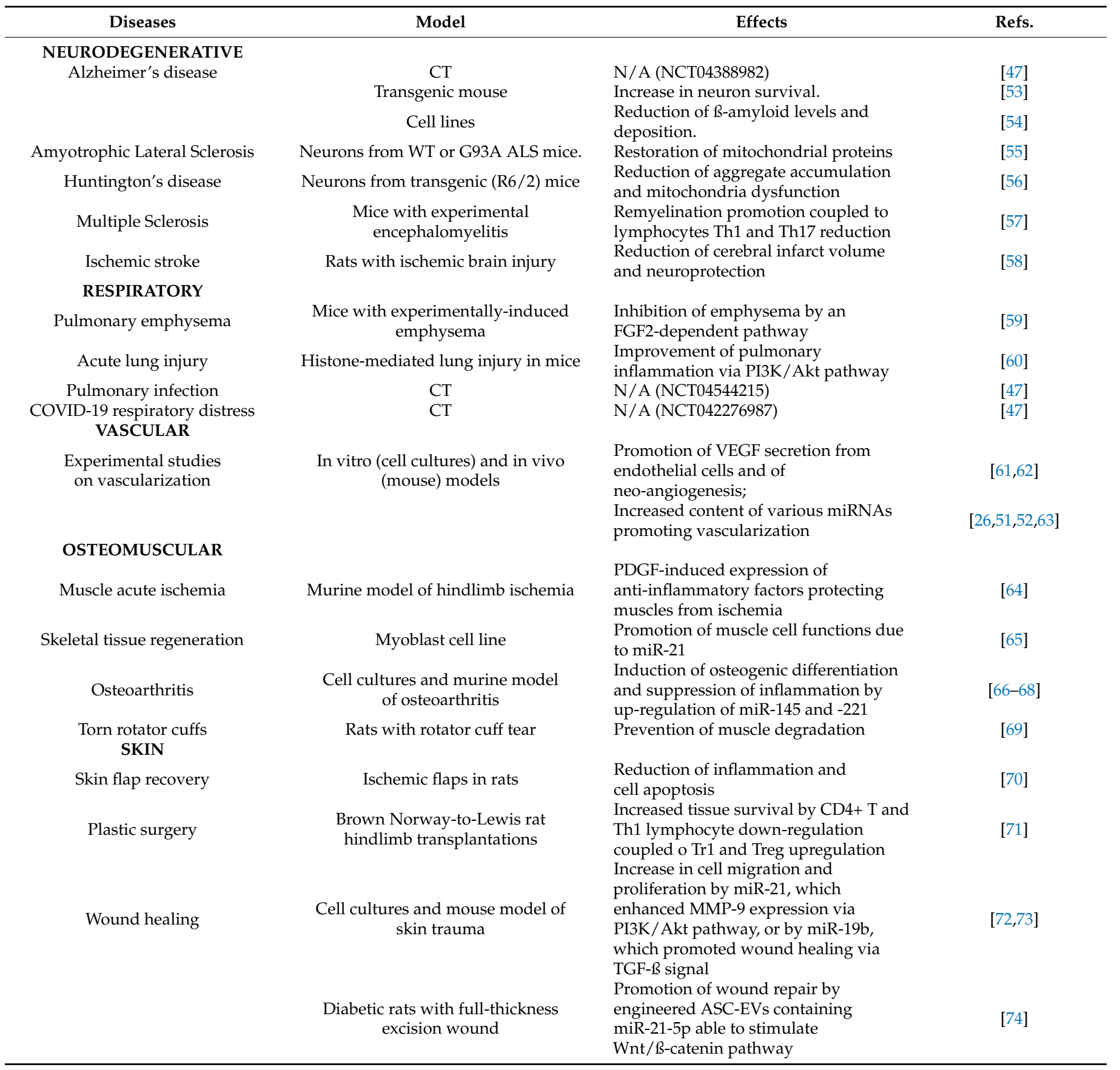

Abbreviations: ALS, amyotrophic lateral sclerosis; ASCs, adipose stromal/stem cells; CT, clinical trial EVs, extracellular vesicles; FGF2, fibroblast growth factor 2; N/A, not available; PDGF, platelet-derived growth factor; PI3K, phosphatidylinositol 3-kinase; TGF-B, transforming growth factor B; VEGF, vascular endothelial growth factor; WT, wild-type.

\section{Experimental Use of ASC-Derived EVs in AT Homeostasis and Disease}

Jung et al. isolated EVs from human ASCs during white or beige differentiation in vitro, observing that EVs from both cell sources could induce the successful differentiation of other ASCs into white or beige adipocytes, promoting adipogenesis in vivo as well [75]. Indeed, intraperitoneal injection of EVs from ASCs that differentiated into white adipocytes promoted the regeneration of AT in mice after 4 weeks, resulting in increased expression levels of specific adipogenic markers such as peroxisome proliferator-activated receptor $\gamma(\operatorname{PPAR} \gamma)$, fatty acid binding protein 4 (FABP4) and leptin. 
On the other hand, BAT-derived EVs prevented diet-induced obesity (DIO) in mice fed a high-fat diet by causing browning of AT while suppressing the accumulation of lipid droplets in liver tissue and restoring glucose homeostasis. The miRNAs contained in these nanoparticles were primarily responsible for the observed effects of BAT-derived EVs. Accordingly, mice with adipose-tissue-specific knockout of the miRNA-processing enzyme Dicer (ADicerKO), as well as humans with lipodystrophy, showed decreased levels of circulating exosomal miRNAs, while transplantation of WAT or BAT into ADicerKO mice restored the level of many circulating miRNAs. This event was associated with an improvement in glucose tolerance and a reduction in hepatic Fgf21 mRNA and circulating FGF21, a hormone that regulates important metabolic pathways [76].

Therefore, EVs secreted during stem cell differentiation into white or beige adipocytes can promote cell reprogramming, acting as a pivot point in fat homeostasis.

Zhao et al. [77] demonstrated that treating obese mice with ASC-derived exosomes isolated from the fat pad of normal-weight mice improved insulin sensitivity, while reducing obesity and hepatic steatosis in these animals. These findings were mainly based on the transfer of EV content to the macrophages, directing them towards an anti-inflammatory M2 phenotype. Interestingly, exosomes also contain high levels of tyrosine hydroxylase, which is responsible for catecholamine release and lactate production, both events favoring the transition of WAT to a beige phenotype and improving metabolic homeostasis in response to the challenge of high-fat food. These findings outline a novel exosome-mediated mechanism for cross-dialogue between ASCs and macrophages.

Notably, the anti-inflammatory behavior of ASC-derived EVs could also be exploited in inflammatory bowel disease (IBD), for which there is no effective and safe treatment. Yu and colleagues [78] recently reported in a mouse model of IBD that exosomes from human ASCs protected the integrity of the gut by activating the proliferation of intestinal epithelial and stem cells. Moreover, the anti-inflammatory/immunomodulatory potential of ASC-derived EVs is now being actively investigated for possible applications in acute and chronic inflammatory conditions, including experimental allergic airway models, ultraviolet $\mathrm{B}$ ray exposure-induced skin alteration or inflammation associated with traumatic brain injury [79-81].

Taken together, these data indicate that EVs could play an important role in immune and metabolic homeostasis in WAT, while also providing a novel tool to control inflammatory processes in obesity [82].

Additionally, the therapeutic potential of ASC-derived EVs has been investigated in models of obesity-related comorbidities such as diabetic nephropathy [83] or delayed wound healing [84]. The administration of ASC-derived exosomes attenuated the negative consequences of spontaneous diabetes in mice, reducing the levels of urinary proteins, serum creatinine, blood urea nitrogen and podocyte apoptosis, which improved the clinical picture of renal insufficiency. The authors ascribed this improvement to the presence of miR-486 within EVs, a key factor capable of reducing the activation of the mammalian target of rapamycin (mTOR). mTOR is a serine/threonine protein kinase belonging to the phosphatidylinositol 3-kinase (PI3K)-related protein kinases (PIKK) family. In mammals, it is the catalytic subunit of two protein complexes known as mTOR complex 1 (mTORC1) and 2 (mTORC2), which have different levels of sensitivity to rapamycin and whose activities are summarized in Figure 2.

Thus, in rats with diabetic nephropathy, inhibition of this molecular pathway by miR486 led to an increase in autophagy, a protective process that is important for maintaining normal cell homeostasis, and a reduction in podocyte apoptosis.

ASC-EV effects, tested in both in vitro and in vivo models, contributed to diabetic wound healing by promoting angiogenesis via the HIF- $1 \alpha$ signaling cascade. In this case, the positive effect was due to the activation of the mTOR complex, with the contribution of the PI3K/Akt pathway [84]. 


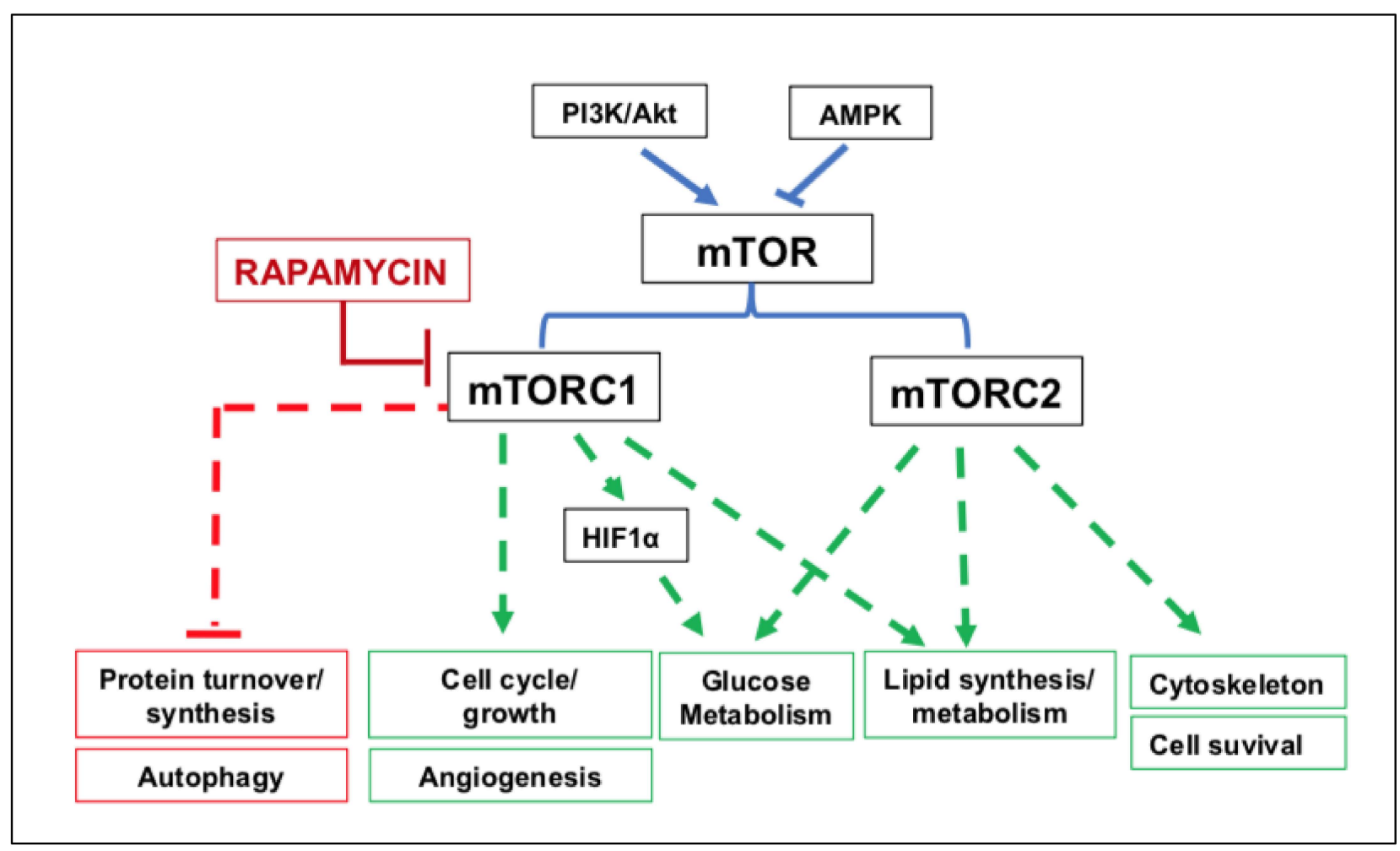

Figure 2. Scheme of the activities promoted by the mTOR (mammalian target of rapamycin) system, composed of two complexes known as mTORC1 and mTORC2, and of its modulation by the phosphatidylinositol 3-kinase (PI3K) and AMP-activated protein kinase (AMPK) pathways. Rapamycin exogenously inhibits the mTOR system, mostly acting on the activities of mTORC1. Arrows drawn with dashed lines indicate that more downstream factors contribute to the final effect caused by the activation of mTORC1 and mTORC2. Abbreviation: HIF1 $\alpha$, hypoxia-inducible factor $1 \alpha$.

Of note, PI3K/Akt and mTOR signals are interconnected and activated by the presence of high levels of insulin and insulin-like growth factor 1 (IGF-1) in overweight/obese subjects [85]. Conversely, caloric restriction inhibits PI3K/Akt/mTOR pathway activation, in part at least, via AMP-activated protein kinase (AMPK) activation [86]. While the interaction between ASC-derived EVs and PI3K and/or AMPK signals needs to be explored, the observations reported above indicate that these nanoparticles, at least in cells that are different from adipocytes, can contribute to the homeostasis of their functions by involving the mTOR pathway. Thus, it would be of interest to explore whether ASC-derived EVs can influence mTOR signaling directly, acting at the adipocyte level, as mTOR is crucial in regulating energy balance/body weight [87] and fat/glucose homeostasis [88].

Specifically, mTORC1 has long been recognized as an epigenetic and post-translational modulator of lipid turnover, and its stimulation promotes the differentiation of preadipocytes in mature cells by activating PPAR $\gamma$. This process enhances lipogenesis, that is, fat accumulation into lipid vacuoles. More recently, mTORC2 activity has been shown to promote adipogenesis, that is, the differentiation of ASCs into pre-adipocytes. mTORC2 also plays a modulatory role on the activity of mTORC1 (reviewed in [87]). Therefore, global deregulation of the mTOR system remarkably alters, among others, lipid homeostasis, leading to the development of obesity. Accordingly, the use of the classic mTOR inhibitor, rapamycin, in cultured human pre-adipocytes inhibited their complete differentiation into adipocytes [89] (see also Figure 3). 


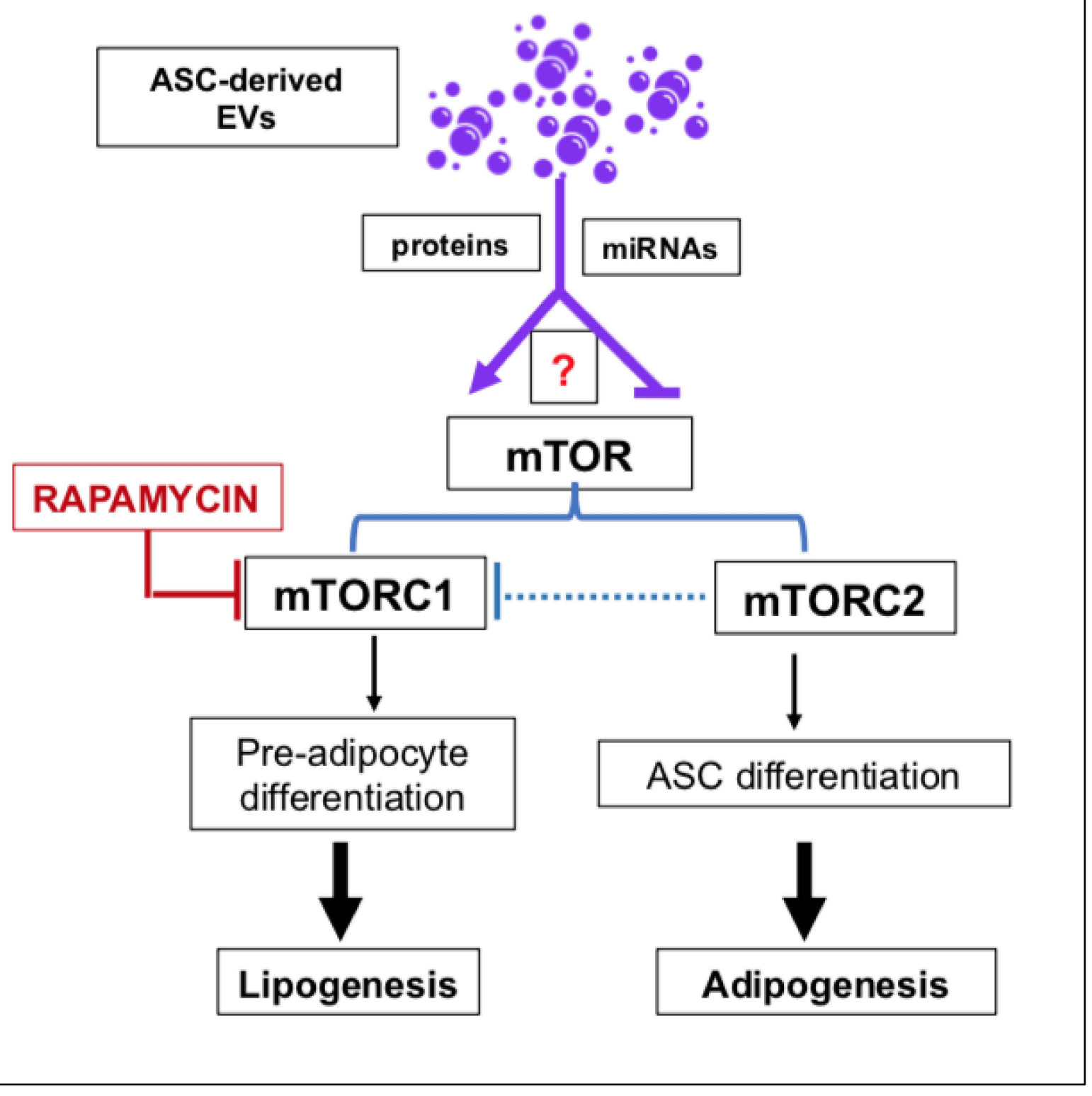

Figure 3. ASC-derived EVs could exert a modulatory role on the activity of the two components (mTORC1 and mTORC2) of the mTOR system in cells of the white adipose tissue (WAT) through the release and donation of selected molecules (miRNAs, proteins). The arrow drawn with a dotted line indicates that $\mathrm{mTORC} 2$ modulates $\mathrm{mTORC}^{\prime} \mathrm{s}$ function, probably inhibiting it. The red question mark indicates that EV-mediated activities have yet to be defined in adipocytes. Abbreviations: ASCs, adipose stromal/stem cells; EVs, extracellular vesicles; miRNAs, microRNAs.

However, this effect was time-dependent. Indeed, only long-term blockade of mTORC1 by rapamycin can reduce DIO in mice [90]. In contrast, it has been reported that the pretreatment of human ASCs with the same drug enhanced autophagy, while reducing apoptosis, delaying senescence, promoting adipogenesis of those cells in vitro and increasing their survival and angiogenesis in vivo [91]. These effects could be explained by the greater sensitivity of mTORC1 to inhibition by rapamycin, which leads to the prevalent activity of mTORC2 (Figure 3). In this scenario, it would also be desirable to investigate which and how much of these effects are mediated by molecules donated from ASC-derived EVs to neighboring cells through the involvement of the mTOR system. 


\section{Advantages and Disadvantages of the Potential Use of ASC-Derived EVs in the Clinic}

Research on EVs is producing substantial results in obesity, attracting pharmaceuticals to develop EV analogs. However, to our knowledge, there is no approved product for any therapeutic application at the present, while EVs, mainly exosomes, are being used for diagnostic purposes (reviewed in [92]). In particular, ASC-EVs could be exploited as a diagnostic tool for the assessment of obesity and the related metabolic complications. In fact, EVs from obese patients are characterized by the presence of specific biomarkers in their content, such as perilipin A, which is associated with insulin resistance, or cystatin C and CD14, which are associated with cardiovascular complications (reviewed in [93]).

Clearly, the therapeutic use of EVs from ASCs in the clinic is also attractive and scientifically supported by the results obtained through a wide variety of experimental pathological conditions, ranging from kidney transplantation to inflammatory bone diseases and tissue regeneration [94-97].

The use of EVs for clinical applications appears to offer several advantages over that with adult stem cells. However, the evidence is not univocal, and there are conflicting results, which exist even for the clinical use of MSCs (see Table 2).

Table 2. Advantages and disadvantages of the use of EVs for future therapeutic/clinical applications.

\begin{tabular}{|c|c|c|c|}
\hline Advantages & Refs. & Disadvantages & Refs. \\
\hline EV use for diagnostic purposes & {$[92,93]$} & $\begin{array}{l}\text { Methods of EV isolation are not yet } \\
\text { fully standardized }\end{array}$ & [98] \\
\hline Good handling & [98] & $\begin{array}{c}\text { EVs' storage stability is not well } \\
\text { known }\end{array}$ & [98] \\
\hline $\begin{array}{l}\text { Small size precluding pulmonary } \\
\text { embolism if administered in a large } \\
\text { number and favoring crossing of the } \\
\text { BBB }\end{array}$ & {$[99,100]$} & $\begin{array}{l}\text { The age of tissue/cell donors } \\
\text { influences the number of ASCs, and } \\
\text { thereby EVs, obtainable from SAT, } \\
\text { even though the results are still } \\
\text { conflicting }\end{array}$ & {$[44,75,101]$} \\
\hline $\begin{array}{l}\text { Low /null expression of membrane } \\
\text { histocompatibility markers, reducing } \\
\text { the risk of host immune responses }\end{array}$ & [99] & $\begin{array}{l}\text { Weight of donors and the presence of } \\
\text { metabolic pathologies can alter EVs' } \\
\text { quality/characteristics }\end{array}$ & {$[29,101,102]$} \\
\hline $\begin{array}{l}\text { EVs carry only a fraction of the } \\
\text { molecules produced by the cells of } \\
\text { origin, favoring selection for specific } \\
\text { therapeutic purposes }\end{array}$ & [100] & $\begin{array}{l}\text { Restriction in the range of products } \\
\text { donated by EVs compared with entire } \\
\text { MSCs, so that the therapeutic dose } \\
\text { and efficacy of EVs must still be } \\
\text { clearly defined }\end{array}$ & [92] \\
\hline $\begin{array}{l}\text { Homing certain tissues depends on } \\
\text { their source tissue, which would be } \\
\text { mainly useful in the case of the use of } \\
\text { EV for targeted drug delivery }\end{array}$ & {$[33]$} & $\begin{array}{l}\text { It is not clear how extensive the EV } \\
\text { homing ability is. }\end{array}$ & [33] \\
\hline $\begin{array}{l}\text { EVs, similar to iPSCs and unlike } \\
\text { MSCs, should not be tumorigenic } \\
\text { and, in selected cases, could also } \\
\text { serve as a new anticancer tool }\end{array}$ & [103-105] & $\begin{array}{c}\text { Data are still conflicting. One should } \\
\text { not forget the angiogenic properties } \\
\text { of EVs, which may favor tumor } \\
\text { growth/expansion or the } \\
\text { development/worsening of } \\
\text { metabolic diseases }\end{array}$ & {$[51,105-107]$} \\
\hline
\end{tabular}

Abbreviations: ASCs, adipose stromal/stem cells; BBB: blood-brain barrier; EVs, extracellular vesicles; iPSCs, induced pluripotent stem cells; MSCs, mesenchymal stem cells, SAT, subcutaneous adipose tissue.

The important features of EVs for their potential application in experimental therapy include good handling [98,99], which should not cause pulmonary embolism, as this can occur with ASCs, when administered in large numbers [100]. The EVs' small size also allows them to cross the blood-brain barrier (BBB) easily after systemic administration, while their low/null expression of membrane histocompatibility markers reduces the risk of host immune responses [99]. Moreover, EVs are more resistant to injuries caused by freeze-thaw cycles and show high in vivo stability [99]. 
However, to date, the methods of EV isolation are not yet fully standardized and, therefore, there is a problem regarding their purification and identification, together with another problem related to the storage stability of EVs in view of their possible therapeutic application [108]. In addition, a general limitation for all potential applications of EVs in therapy is the age of the tissue/cell donors. As with AT, it has been reported that the number of ASCs obtainable from SAT decreases with age [101]; probably, the same happens for ASC-derived EVs [44]. Unfortunately, results on the differences in EV characteristics obtained from young and senescent cells are still conflicting [101]. Another important issue is the weight of the donors [102], as well as the presence of metabolic pathologies [29], which reasonably alter the quality and characteristics of the EVs obtained from those cells [109].

Furthermore, it must be considered that EVs carry only a fraction of the molecules produced by the cells of origin, which are selected for specific purposes such as supplying neighboring/distal cells with energetically, biochemically or enzymatically useful materials, as well as nucleic acids, which can alter the expression of the target genes. This can be an advantage but also as a disadvantage, considering the restriction in the range of products donated by EVs compared with entire MSCs [96], and also implies that the therapeutic dose and efficacy of EVs must still be clearly defined. Furthermore, EVs can home in on certain tissues depending on their source tissue, which would be mainly useful in the case of EV use for targeted drug delivery [33], although it is not clear how extensive this homing ability is.

Notably, MSCs can undergo spontaneous transformation and may therefore be tumorigenic. A decreased carcinogenic potential has been shown by induced pluripotent stem cells (iPSCs) [103], which are pluripotent stem cells generated from somatic cells. iPSCs can be differentiated into MSCs and expanded to generate a large population of homogeneous MSCs. However, further studies are warranted to determine the safety of iPSCs before their use in clinical trials. The same point should be considered for EVs, which do not have carcinogenic characteristics [98], although we should not overlook the fact that, similar to ASCs, EVs can also present a tumorigenic risk. For example, in patients with ovarian cancer, omental AT, which contains numerous ASCs, appears to promote tumor growth via paracrine secretion supported by ASC-derived EVs [106]. In fact, these EVs, secreted in the extracellular space, allow communication between tumor cells and ASCs with macrophages and immune cells, potentially favoring cancer progression and drug resistance. Again, as reported above, ASC-derived EVs show angiogenic properties [50], which may also favor tumor expansion and metastasis. However, there is also some opposing evidence. Thus, in immunocompetent mouse models of breast cancer, Li and colleagues [105] identified ASCs endowed with a typical mesenchymal stem marker, CD90, which had different expression levels, namely CD90 high and CD90 ${ }^{\text {low }}$ ASCs. Interestingly, the CD90 ${ }^{\text {low }}$ cell subset and its derived EVs significantly inhibited tumor growth in tumor-bearing mice, decreasing cancer cell proliferation and migration and enhancing their apoptosis. Therefore, EVs derived from ASCs and other stem cell sources could also serve as a new anticancer tool.

Finally, it should be noted that obesity severely modifies the properties of EVs, enhancing their inflammatory profile [49] as well as the activity of HIFs contained in ASC-derived EVs [51], which could also promote metabolic diseases, as observed in diet-induced disease models [107]. Thus, biotechnological modification of the EVs aimed at eliminating these factors could be useful for the treatment of those disorders. In particular, EVs can be engineered to generate EVs with modified/enhanced therapeutic properties or tissue tropism [110]. Additionally, EVs can be helped to find target cells/tissues by adopting delivery alternatives such as hydrogel encapsulation to favor locally sustained persistence of these nanoparticles [111].

\section{Conclusions}

In conclusion, ASC-derived EVs play an important role in the modulation of metabolic processes and could be exploited as a valid diagnostic tool in obesity and in metabolic syn- 
drome, for the management of which they also represent an attractive cell-free therapeutic tool.

These clinical applications undoubtedly open up a fascinating scenario for the development of a new generation of anti-obesity agents. However, although the safe/appropriate use of EVs in clinical practice appears feasible and tangible, standardized good manufacturing practices (GMPs) for the clinical GMP-grade production of EVs are needed for the optimization of cell cultures, purification, quantification and quality control $[112,113]$.

Author Contributions: Conceptualization, R.C. and P.D.I.; data curation, M.Z., P.G., V.D.L., M.F., V.C., F.C., G.M. and P.D.I.; writing-original draft preparation, R.C.; writing-review and editing, all authors; supervision, R.C. All authors have read and agreed to the published version of the manuscript.

Funding: This research was partly funded by the University of Chieti-Pescara, grant number AT2020 to P.D.I.

Institutional Review Board Statement: Not applicable.

Informed Consent Statement: Not applicable.

Data Availability Statement: Not applicable.

Conflicts of Interest: The authors declare no conflict of interest.

\section{Abbreviations}

ADicerKO knockout of the miRNA-processing enzyme Dicer

ALS amyotrophic lateral sclerosis

AMPK AMP-activated protein kinase

ASCs adipose stromal/stem cells

AT adipose tissue

BAT brown adipose tissue

BBB blood-brain barrier

BM-MSCs bone marrow-derived MSCs

CT clinical trial

DIO diet-induced obesity

Dlk1 Notch1 inhibitor delta-like 1 homolog

EVs extracellular vesicles

FAs fatty acids

FABP4 fatty acid binding protein 4

FGF2 or 21 fibroblast growth factor 2 or 21

FIH-1 inhibitor of hypoxia-inducible factor 1

GMPs good manufacturing practices

$\operatorname{HIF-1}(\alpha) \quad$ hypoxia-inducible factor $1(\alpha)$

IBD inflammatory bowel disease

IGF-1 Insulin like growth factor 1

iPSC induced pluripotent stem cells

MAPK mitogen-activated protein kinase

miRNA(s) microRNA(s)

MMP-2 matrix metalloproteinase 2

MSCs mesenchymal stromal/stem cells

mTOR mammalian target of rapamycin

N/A not available

NF-kB nuclear factor $k B$

PDGF platelet-activated growth factor

PI3K phosphatidylinositol 3-kinase

PPAR $\gamma$ peroxisome proliferator-activated receptor $\gamma$

PPIK PI3K-related protein kinases

TGF- $\beta$ transforming growth factor $B$ 


$\begin{array}{ll}\text { mTORC1 } & \text { mTOR complex } 1 \\ \text { mTORC2 } & \text { mTOR complex } 2 \\ \text { SAT } & \text { subcutaneous adipose tissue } \\ \text { VAT } & \text { visceral adipose tissue } \\ \text { VEGF } & \text { vascular endothelial growth factor } \\ \text { WAT } & \text { white adipose tissue }\end{array}$

\section{References}

1. Hales, C.M.; Carroll, M.D.; Fryar, C.D.; Ogden, C.L. Prevalence of Obesity and Severe Obesity Among Adults, United States; 2017-2018. NCHS Data Brief. 2020, 360, 1-8.

2. Wulan, S.N.; Raza, Q.; Prasmita, H.S.; Martati, E.; Maligan, J.M.; Mageshwari, U.; Fatima, I.; Plasqui, G. Energy Metabolism in Relation to Diet and Physical Activity: A South Asian Perspective. Nutrients 2021, 13, 3776. [CrossRef] [PubMed]

3. Obesity, Preventing and Managing the Global Epidemic; Report of a WHO Consultation; World Health Organization Technical Report Series; World Health Organization: Geneva, Switzerland, 2000; Volume 894, i-xii; pp. 1-253.

4. Lin, X.; Li, H. Obesity, Epidemiology, Pathophysiology and Therapeutics. Front. Endocrinol. 2021, 12, 706978. [CrossRef] [PubMed]

5. Silveira Rossi, J.L.; Barbalho, S.M.; Reverete de Araujo, R.; Bechara, M.D.; Portero Sloan, K.; Sloan, L.A. Metabolic syndrome and cardiovascular diseases, going beyond traditional risk factors. Diabetes Metab. Res. Rev. 2021, 6, e3502. [CrossRef]

6. Castro, B.B.A.; Foresto-Neto, O.; Saraiva-Camara, N.O.; Sanders-Pinheiro, H. Renal lipotoxicity, Insights from experimental models. Clin. Exp. Pharmacol. Physiol. 2021, 48, 1579-1588. [CrossRef]

7. Mili, N.; Paschou, S.A.; Goulis, D.G.; Dimopoulos, M.A.; Lambrinoudaki, I.; Psaltopoulou, T. Obesity, metabolic syndrome, and cancer, pathophysiological and therapeutic associations. Reg. Environ. Chang. 2021, 17, 1725-1737. [CrossRef]

8. Tchang, B.G.; Aras, M.; Kumar, R.B.; Aronne, L.J. Pharmacologic Treatment of Overweight and Obesity in Adults. In Endotext; Feingold, K.R., Anawalt, B., Boyce, A., Chrousos, G., de Herder, W.W., Dhatariya, K., Dungan, K., Grossman, A., Hershman, J.M., Hofland, J., et al., Eds.; MDText.com. Inc.: South Dartmouth, MA, USA, 2000.

9. Pittenger, M.F.; MacKay, A.M.; Beck, S.C.; Jaiswal, R.K.; Douglas, R.; Mosca, J.D.; Moorman, M.A.; Simonetti, D.W.; Craig, S.; Marshak, D.R. Multilineage potential of adult human mesenchymal stem cells. Science 1999, 284, 143-147. [CrossRef]

10. Milan, G.; Conci, S.; Sanna, M.; Favaretto, F.; Bettini, S.; Vettor, R. ASCs and their role in obesity and metabolic diseases. Trends Endocrinol. Metab. 2021, 32, 994-1006. [CrossRef]

11. Hwang, I.; Kim, J.B. Two Faces of White Adipose Tissue with Heterogeneous Adipogenic Progenitors. Diabetes Metab. J. 2019, 43, 752-762. [CrossRef]

12. Li, C.J.; Fang, Q.H.; Liu, M.L.; Lin, J.N. Current understanding of the role of Adipose-derived Extracellular Vesicles in Metabolic Homeostasis and Diseases, Communication from the distance between cells/tissues. Theranostics 2020, 10, 7422-7435. [CrossRef]

13. Saito, M.; Matsushita, M.; Yoneshiro, T.; Okamatsu-Ogura, Y. Brown adipose tissue, diet-induced thermogenesis, and thermogenic food ingredients, from mice to men. Front. Endocrinol. 2020, 11, 222. [CrossRef] [PubMed]

14. Villarroya, J.; Cereijo, R.; Gavaldà-Navarro, A.; Peyrou, M.; Giralt, M.; Villarroya, F. New insights into the secretory functions of brown adipose tissue. J. Endocrinol. 2019, 243, R19-R27. [CrossRef]

15. Harvey, I.; Boudreau, A.; Stephens, J.M. Adipose tissue in health and disease. Open Biol. 2020, 10, 200291. [CrossRef] [PubMed]

16. Blaszczak, A.M.; Jalilvand, A.; Hsueh, W.A. Adipocytes, Innate Immunity and Obesity, A Mini-Review. Front. Immunol. 2021, 12, 650768. [CrossRef] [PubMed]

17. Bourin, P.; Bunnell, B.A.; Casteilla, L.; Dominici, M.; Katz, A.J.; March, K.L.; Redl, H.; Rubin, J.P.; Yoshimura, K.; Gimble, J.M. Stromal cells from the adipose tissue-derived stromal vascular fraction and culture expanded adipose tissue-derived stromal/stem cells, a joint statement of the International Federation for Adipose Therapeutics and Science (IFATS) and the International Society for Cellular Therapy (ISCT). Cytotherapy 2013, 15, 641-648. [CrossRef] [PubMed]

18. Ong, W.K.; Tan, C.S.; Chan, K.L.; Goesantoso, G.G.; Chan, X.H.; Chan, E.; Yin, J.; Yeo, C.R.; Khoo, C.M.; So, J.B.; et al. Identification of specific cell-surface markers of adipose-derived stem cells from subcutaneous and visceral fat depots. Stem Cell Rep. 2014, 2 , 171-179. [CrossRef] [PubMed]

19. Kahn, C.R.; Wang, G.; Lee, K.Y. Altered adipose tissue and adipocyte function in the pathogenesis of metabolic syndrome. J. Clin. Investig. 2019, 129, 3990-4000. [CrossRef] [PubMed]

20. Baglioni, S.; Francalanci, M.; Squecco, R.; Lombardi, A.; Cantini, G.; Angeli, R.; Gelmini, S.; Guasti, D.; Benvenuti, S.; Annunziato, F.; et al. Characterization of human adult stem-cell populations isolated from visceral and subcutaneous adipose tissue. FASEB J. 2009, 23, 3494-3505. [CrossRef] [PubMed]

21. Tchkonia, T.; Thomou, T.; Zhu, Y.; Karagiannides, I.; Pothoulakis, C.; Jensen, M.D.; Kirkland, J.L. Mechanisms and metabolic implications of regional differences among fat depots. Cell Metab. 2013, 17, 644-656. [CrossRef]

22. Kim, B.; Lee, B.; Kim, M.K.; Gong, S.P.; Park, H.Y.; Chung, Y.Y.; Kim, H.S.; No, J.H.; Park, W.Y.; Park, A.K. Gene expression profiles of human subcutaneous and visceral adipose-derived stem cells. Cell Biochem. Funct. 2016, 34, 563-571. [CrossRef]

23. Porro, S.; Genchi, V.A.; Cignarelli, A.; Natalicchio, A.; Laviola, L.; Giorgino, F.; Perrini, S. Dysmetabolic adipose tissue in obesity, morphological and functional characteristics of adipose stem cells and mature adipocytes in healthy and unhealthy obese subjects. J. Endocrinol. Investig. 2021, 44, 921-941. [CrossRef] [PubMed] 
24. Arner, P.; Bernard, S.; Salehpour, M.; Possnert, G.; Liebl, J.; Steier, P.; Buchholz, B.A.; Eriksson, M.; Arner, E.; Hauner, H.; et al. Dynamics of human adipose lipid turnover in health and metabolic disease. Nature 2011, 478, 110-113. [CrossRef] [PubMed]

25. Liu, W.; Li, D.; Cao, H.; Li, H.; Wang, Y. Expansion and inflammation of white adipose tissue-Focusing on adipocyte progenitors. Biol. Chem. 2020, 402, 123-132. [CrossRef] [PubMed]

26. Silva, F.J.; Holt, D.J.; Vargas, V.; Yockman, J.; Boudina, S.; Atkinson, D.; Grainger, D.W.; Revelo, M.P.; Sherman, W.; Bull, D.A. Metabolically Active Human Brown Adipose Tissue Derived Stem Cells. Stem Cells 2014, 32, 572-581. [CrossRef] [PubMed]

27. Fingeret, M.; Marques-Vidal, P.; Vollenweider, P. Incidence of type 2 diabetes, hypertension, and dyslipidemia in metabolically healthy obese and non-obese. Nutr. Metab. Cardiovasc. Dis. 2018, 28, 1036-1044. [CrossRef]

28. Badimon, L.; Cubedo, J. Adipose tissue depots and inflammation, effects on plasticity and resident mesenchymal stem cell function. Cardiovasc. Res. 2017, 113, 1064-1073. [CrossRef]

29. Serena, C.; Keiran, N.; Ceperuelo-Mallafre, V.; Ejarque, M.; Fradera, R.; Roche, K.; Nuñez-Roa, C.; Vendrell, J.; Fernández-Veledo, S. Obesity and Type 2 Diabetes Alters the Immune Properties of Human Adipose Derived Stem Cells. Stem Cells 2016, 34, $2559-2573$. [CrossRef]

30. Lefevre, C.; Chartoire, D.; Ferraz, J.C.; Verdier, T.; Pinteur, C.; Chanon, S.; Pesenti, S.; Vieille-Marchiset, A.; Genestier, L.; Vidal, H.; et al. Obesity activates immunomodulating properties of mesenchymal stem cells in adipose tissue with differences between localizations. FASEB J. 2021, 35, e21650. [CrossRef]

31. Ong, W.K.; Chakraborty, S.; Sugii, S. Adipose Tissue, Understanding the Heterogeneity of Stem Cells for Regenerative Medicine. Biomolecules 2021, 11, 918. [CrossRef]

32. Perin, E.C.; Sanz-Ruiz, R.; Sánchez, P.L.; Lasso, J.; Pérez-Cano, R.; Alonso-Farto, J.C.; Pérez-David, E.; Fernández-Santos, M.E.; Serruys, P.W.; Duckers, H.J.; et al. Adipose-derived regenerative cells in patients with ischemic cardiomyopathy, The PRECISE Trial. Am. Heart J. 2014, 168, 88-95.e2. [CrossRef]

33. Claridge, B.; Lozano, J.; Poh, Q.H.; Greening, D.W. Development of Extracellular Vesicle Therapeutics, Challenges, Considerations, and Opportunities. Front. Cell Dev. Biol. 2021, 9, 734720. [CrossRef] [PubMed]

34. Théry, C.; Witwer, K.W.; Aikawa, E.; Alcaraz, M.J.; Anderson, J.D.; Andriantsitohaina, R.; Antoniou, A.; Arab, T.; Archer, F.; Atkin-Smith, G.K.; et al. Minimal information for studies of extracellular vesicles 2018 (MISEV2018), a position statement of the International Society for Extracellular Vesicles and update of the MISEV2014 guidelines. J. Extracell. Vesicles 2018, 7, 1535750. [CrossRef]

35. Keller-Pinter, A.; Bottka, S.; Timar, J.; Kulka, J.; Katona, R.; Dux, L.; Deak, F.; Szilak, L. Syndecan-4 promotes cytokinesis in a phosphorylation-dependent manner. Cell Mol. Life Sci. 2010, 67, 1881-1894. [CrossRef] [PubMed]

36. Yáñez-Mó, M.; Siljander, P.R.; Andreu, Z.; Zavec, A.B.; Borràs, F.E.; Buzas, E.I.; Buzas, K.; Casal, E.; Cappello, F.; Carvalho, J.; et al. Biological properties of extracellular vesicles and their physiological functions. J. Extracell. Vesicles 2015, 4, 27066. [CrossRef] [PubMed]

37. Huang, Z.; Xu, A. Adipose Extracellular Vesicles in Intercellular and Inter-Organ Crosstalk in Metabolic Health and Diseases. Front. Immunol. 2021, 12, 608680. [CrossRef] [PubMed]

38. Chen, Y.; Pfeifer, A. Brown fat-derived exosomes, small vesicles with big impact. Cell Metab. 2017, 25, 759-760. [CrossRef]

39. Gómez-Serrano, M.; Ponath, V.; Preußer, C.; Pogge von Strandmann, E. Beyond the Extracellular Vesicles, Technical Hurdles, Achieved Goals and Current Challenges When Working on Adipose Cells. Int. J. Mol. Sci. 2021, 22, 3362. [CrossRef]

40. Lötvall, J.; Hill, A.F.; Hochberg, F.; Buzás, E.I.; Di Vizio, D.; Gardiner, C.; Gho, Y.S.; Kurochkin, I.V.; Mathivanan, S.; Quesenberry, P.; et al. Minimal experimental requirements for definition of extracellular vesicles and their functions, a position statement from the International Society for Extracellular Vesicles. J. Extracell. Vesicles 2014, 3, 26913. [CrossRef]

41. Zhu, L.L.; Huang, X.; Yu, W.; Chen, H.; Chen, Y.; Dai, Y.T. Transplantation of adipose tissue-derived stem cell-derived exosomes ameliorates erectile function in diabetic rats. Andrologia 2018, 50, e12871. [CrossRef]

42. Eirin, A.; Riester, S.M.; Zhu, X.Y.; Tang, H.; Evans, J.M.; O’Brien, D.; van Wijnen, A.J.; Lerman, L.O. MicroRNA and mRNA cargo of extracellular vesicles from porcine adipose tissue-derived mesenchymal stem cells. Gene 2014, 551, 55-64. [CrossRef]

43. Eirin, A.; Meng, Y.; Zhu, X.Y.; Li, Y.; Saadiq, I.M.; Jordan, K.L.; Tang, H.; Lerman, A.; van Wijnen, A.J.; Lerman, L.O. The Micro-RNA Cargo of Extracellular Vesicles Released by Human Adipose Tissue-Derived Mesenchymal Stem Cells Is Modified by Obesity. Front. Cell Dev. Biol. 2021, 9, 660851. [CrossRef] [PubMed]

44. Conley, S.M.; Shook, J.E.; Zhu, X.Y.; Eirin, A.; Jordan, K.L.; Woollard, J.R.; Isik, B.; Hickson, L.J.; Puranik, A.S.; Lerman, L.O. Metabolic Syndrome Induces Release of Smaller Extracellular Vesicles from Porcine Mesenchymal Stem Cells. Cell Transplant. 2019, 28, 1271-1278. [CrossRef] [PubMed]

45. Eirin, A.; Ferguson, C.M.; Zhu, X.Y.; Saadiq, I.M.; Tang, H.; Lerman, A.; Lerman, L.O. Extracellular vesicles released by adipose tissue-derived mesenchymal stromal/stem cells from obese pigs fail to repair the injured kidney. Stem Cell Res. 2020, $47,101877$. [CrossRef] [PubMed]

46. Trzyna, A.; Banaś-Zabczyk, A. Adipose-Derived Stem Cells Secretome and Its Potential Application in "Stem Cell-Free Therapy". Biomolecules 2021, 11, 878. [CrossRef] [PubMed]

47. Xing, X.; Han, S.; Cheng, G.; Ni, Y.; Li, Z.; Li, Z. Proteomic Analysis of Exosomes from Adipose-Derived Mesenchymal Stem Cells, A Novel Therapeutic Strategy for Tissue Injury. Biomed. Res. Int. 2020, 2020, 6094562. [CrossRef] [PubMed] 
48. Ni, J.; Li, H.; Zhou, Y.; Gu, B.; Xu, Y.; Fu, Q.; Peng, X.; Cao, N.; Fu, Q.; Jin, M.; et al. Therapeutic Potential of Human AdiposeDerived Stem Cell Exosomes in Stress Urinary Incontinence-An in Vitro and in Vivo Study. Cell. Physiol. Biochem. 2018, 48, 1710-1722. [CrossRef] [PubMed]

49. Alonso-Alonso, M.L.; García-Posadas, L.; Diebold, Y. Extracellular Vesicles from Human Adipose-Derived Mesenchymal Stem Cells, A Review of Common Cargos. Stem Cell Rev. Rep. 2021. [CrossRef] [PubMed]

50. Domenis, R.; Cifù, A.; Quaglia, S.; Pistis, C.; Moretti, M.; Vicario, A.; Parodi, P.C.; Fabris, M.; Niazi, K.R.; Soon-Shiong, P.; et al. Pro inflammatory stimuli enhance the immunosuppressive functions of adipose mesenchymal stem cells-derived exosomes. Sci. Rep. 2018, 8, 13325. [CrossRef]

51. Rautiainen, S.; Laaksonen, T.; Koivuniemi, R. Angiogenic Effects and Crosstalk of Adipose-Derived Mesenchymal Stem/Stromal Cells and Their Extracellular Vesicles with Endothelial Cells. Int. J. Mol. Sci. 2021, 22, 10890. [CrossRef] [PubMed]

52. Schober, A.; Nazari-Jahantigh, M.; Wei, Y.; Bidzhekov, K.; Gremse, F.; Grommes, J.; Megens, R.T.; Heyll, K.; Noels, H.; Hristov, M.; et al. MicroRNA-126-5p promotes endothelial proliferation and limits atherosclerosis by suppressing Dlk1. Nat. Med. 2014, 20, 368-376. [CrossRef]

53. Lee, M.; Ban, J.-J.; Yang, S.; Im, W.; Kim, M. The exosome of adipose-derived stem cells reduces $\beta$-amyloid pathology and apoptosis of neuronal cells derived from the transgenic mouse model of Alzheimer's disease. Brain Res. 2018, 1691, 87-93. [CrossRef] [PubMed]

54. Katsuda, T.; Tsuchiya, R.; Kosaka, N.; Yoshioka, Y.; Takagaki, K.; Oki, K.; Takeshita, F.; Sakai, Y.; Kuroda, M.; Ochiya, T. Human adipose tissue-derived mesenchymal stem cells secrete functional neprilysin-bound exosomes. Sci. Rep. 2013, 3, 1197. [CrossRef] [PubMed]

55. Lee, M.; Ban, J.-J.; Kim, K.Y.; Jeon, G.S.; Im, W.; Sung, J.-J.; Kim, M. Adipose-derived stem cell exosomes alleviate pathology of amyotrophic lateral sclerosis in vitro. Biochem. Biophys. Res. Commun. 2016, 479, 434-439. [CrossRef] [PubMed]

56. Lee, M.; Liu, T.; Im, W.; Kim, M. Exosomes from adipose-derived stem cells ameliorate phenotype of Huntington's disease in vitro model. Eur. J. Neurosci. 2016, 44, 2114-2119. [CrossRef] [PubMed]

57. Laso-García, F.; Ramos-Cejudo, J.; Carrillo-Salinas, F.J.; Ortega, L.O.; Feliú, A.; Frutos, M.G.-D.; Mecha, M.; Díez-Tejedor, E.; Guaza, C.; Gutiérrez-Fernández, M. Therapeutic potential of extracellular vesicles derived from human mesenchymal stem cells in a model of progressive multiple sclerosis. PLoS ONE 2018, 13, e0202590. [CrossRef] [PubMed]

58. Chen, K.H.; Chen, C.H.; Wallace, C.G.; Yuen, C.M.; Kao, G.-S.; Chen, Y.L.; Shao, P.L.; Chen, Y.L.; Chai, H.T.; Lin, K.C.; et al Intravenous administration of xenogenic adipose-derived mesenchymal stem cells (ADMSC) and ADMSC-derived exosomes markedly reduced brain infarct volume and preserved neurological function in rat after acute ischemic stroke. Oncotarget 2016, 7, 74537-74556. [CrossRef] [PubMed]

59. Kim, Y.-S.; Kim, J.-Y.; Cho, R.; Shin, D.-M.; Lee, S.W.; Oh, Y.-M. Adipose stem cell-derived nanovesicles inhibit emphysema primarily via an FGF2-dependent pathway. Exp. Mol. Med. 2017, 49, e284. [CrossRef]

60. Mizuta, Y.; Akahoshi, T.; Guo, J.; Zhang, S.; Narahara, S.; Kawano, T.; Murata, M.; Tokuda, K.; Eto, M.; Hashizume, M.; et al Exosomes from adipose tissue-derived mesenchymal stem cells ameliorate histone-induced acute lung injury by activating the PI3K/Akt pathway in endothelial cells. Stem Cell Res. Ther. 2020, 11, 508. [CrossRef]

61. Zhu, Y.; Zhang, J.; Hu, X.; Wang, Z.; Wu, S.; Yi, Y. Extracellular vesicles derived from human adipose-derived stem cells promote the exogenous angiogenesis of fat grafts via the let-7/AGO1/VEGF signalling pathway. Sci. Rep. 2020, 10, 5313. [CrossRef]

62. Yu, F.; Witman, N.; Yan, D.; Zhang, S.; Zhou, M.; Yan, Y.; Yao, Q.; Ding, F.; Yan, B.; Wang, H.; et al. Human adipose-derived stem cells enriched with VEGF-modified mRNA promote angiogenesis and long-term graft survival in a fat graft transplantation model. Stem Cell Res. Ther. 2020, 11, 490. [CrossRef]

63. An, Y.; Zhao, J.; Nie, F.; Qin, Z.; Xue, H.; Wang, G.; Li, D. Exosomes from Adipose-Derived Stem Cells (ADSCs) Overexpressing miR-21 Promote Vascularization of Endothelial Cells. Sci. Rep. 2019, 9, 12861. [CrossRef] [PubMed]

64. Lopatina, T.; Favaro, E.; Grange, C.; Cedrino, M.; Ranghino, A.; Occhipinti, S.; Fallo, S.; Buffolo, F.; Gaykalova, D.A.; Zanone, M.M.; et al. PDGF enhances the protective effect of adipose stem cell-derived extracellular vesicles in a model of acute hindlimb ischemia. Sci. Rep. 2018, 8, 17458. [CrossRef] [PubMed]

65. Mitchell, R.; Mellows, B.; Sheard, J.; Antonioli, M.; Kretz, O.; Chambers, D.; Zeuner, M.-T.; Tomkins, J.E.; Denecke, B.; Musante, L.; et al. Secretome of adipose-derived mesenchymal stem cells promotes skeletal muscle regeneration through synergistic action of extracellular vesicle cargo and soluble proteins. Stem Cell Res. Ther. 2019, 10, 116. [CrossRef] [PubMed]

66. Zhu, M.; Liu, Y.; Qin, H.; Tong, S.; Sun, Q.; Wang, T.; Zhang, H.; Cui, M.; Guo, S. Osteogenically-induced exosomes stimulate osteogenesis of human adipose-derived stem cells. Cell Tissue Bank. 2021, 22, 77-91. [CrossRef]

67. Zhao, C.; Chen, J.; Peng, W.; Yuan, B.; Bi, Q.; Xu, Y. Exosomes from adipose-derived stem cells promote chondrogenesis and suppress inflammation by upregulating miR-145 and miR-221. Mol. Med. Rep. 2020, 21, 1881-1889. [CrossRef]

68. Tofiño-Vian, M.; Guillén, M.I.; DelCaz, M.D.P.; Silvestre, A.; Alcaraz, M.J. Microvesicles from Human Adipose Tissue-Derived Mesenchymal Stem Cells as a New Protective Strategy in Osteoarthritic Chondrocytes. Cell. Physiol. Biochem. 2018, 47, 11-25. [CrossRef]

69. Wang, C.; Song, W.; Chen, B.; Liu, X.; He, Y. Exosomes Isolated from Adipose-Derived Stem Cells: Anew Cell-Free Approach to Prevent the Muscle Degeneration Associated with Torn Rotator Cuffs. Am. J. Sports Med. 2019, 47, 3247-3255. [CrossRef] 
70. Bai, Y.; Han, Y.-D.; Yan, X.-L.; Ren, J.; Zeng, Q.; Li, X.-D.; Pei, X.-T.; Han, Y. Adipose mesenchymal stem cell-derived exosomes stimulated by hydrogen peroxide enhanced skin flap recovery in ischemia-reperfusion injury. Biochem. Biophys. Res. Commun. 2018, 500, 310-317. [CrossRef]

71. Chen, Z.; Xue, S.; Zhang, S.; Cheng, K.; Ye, Q. Exosomes from donor-derived adipose mesenchymal stem cells prolong the survival of vascularized composite allografts. J. Cell. Physiol. 2021, 236, 5895-5905. [CrossRef]

72. Yang, C.; Luo, L.; Bai, X.; Shen, K.; Liu, K.; Wang, J.; Hu, D. Highly-expressed microRNA-21 in adipose derived stem cell exosomes can enhance the migration and proliferation of the HaCaT cells by increasing the MMP-9 expression through the PI3K/AKT pathway. Arch. Biochem. Biophys. 2020, 681, 108259. [CrossRef]

73. Cao, G.; Chen, B.; Zhang, X.; Chen, H. Human Adipose-Derived Mesenchymal Stem Cells-Derived Exosomal microRNA-19b Promotes the Healing of Skin Wounds through Modulation of the CCL1/TGF- $\beta$ Signaling Axis. Clin. Cosmet. Investig. Dermatol. 2020, 13, 957-971. [CrossRef] [PubMed]

74. Lv, Q.; Deng, J.; Chen, Y.; Wang, Y.; Liu, B.; Liu, J. Engineered Human Adipose Stem-Cell-Derived Exosomes Loaded with miR-21-5p to Promote Diabetic Cutaneous Wound Healing. Mol. Pharm. 2020, 17, 1723-1733. [CrossRef] [PubMed]

75. Jung, Y.J.; Kim, H.K.; Cho, Y.; Choi, J.S.; Woo, C.H.; Lee, K.S.; Sul, J.H.; Lee, C.M.; Han, J.; Park, J.H.; et al. Cell reprogramming using extracellular vesicles from differentiating stem cells into white/beige adipocytes. Sci. Adv. 2020, 6, eaay6721. [CrossRef] [PubMed]

76. Thomou, T.; Mori, M.A.; Dreyfuss, J.M.; Konishi, M.; Sakaguchi, M.; Wolfrum, C.; Rao, T.N.; Winnay, J.N.; Garcia-Martin, R.; Grinspoon, S.K.; et al. Adipose-derived circulating miRNAs regulate gene expression in other tissues. Nature 2017, 542, 450-455. [CrossRef]

77. Zhao, H.; Shang, Q.; Pan, Z.; Bai, Y.; Li, Z.; Zhang, H.; Zhang, Q.; Guo, C.; Zhang, L.; Wang, Q. Exosomes From Adipose-Derived Stem Cells Attenuate Adipose Inflammation and Obesity Through Polarizing M2 Macrophages and Beiging in White Adipose Tissue. Diabetes 2018, 67, 235-247. [CrossRef] [PubMed]

78. Yu, H.; Yang, X.; Xiao, X.; Xu, M.; Yang, Y.; Xue, C.; Li, X.; Wang, S.; Zhao, R.C. Human Adipose Mesenchymal Stem Cellderived Exosomes Protect Mice from DSS-Induced Inflammatory Bowel Disease by Promoting Intestinal-stem-cell and Epithelial Regeneration. Aging Dis. 2021, 12, 1423-1437. [CrossRef] [PubMed]

79. Cho, K.S.; Kang, S.A.; Kim, S.D.; Mun, S.J.; Yu, H.S.; Roh, H.J. Dendritic cells and M2 macrophage play an important role in suppression of Th2-mediated inflammation by adipose stem cells-derived extracellular vesicles. Stem Cell Res. 2019, 39, 101500. [CrossRef] [PubMed]

80. Xu, P.; Xin, Y.; Zhang, Z.; Zou, X.; Xue, K.; Zhang, H.; Xue, C.; Han, Q.; Wei, J.; Zhao, R.C. Extracellular Vesicles From AdiposeDerived Stem Cells Ameliorate Ultraviolet B-Induced Skin Photoaging by Attenuating Reactive Oxygen Species Production and Inflammation. Stem Cell Res. Ther. 2020, 11, 264. [CrossRef]

81. Chen, Y.; Li, J.; Ma, B.; Li, N.; Wang, S.; Sun, Z.; Xue, C.; Han, Q.; Wei, J.; Zhao, R.C. MSC-Derived Exosomes Promote Recovery From Traumatic Brain Injury Via Microglia/Macrophages in Rat. Aging 2020, 12, 18274-18296. [CrossRef] [PubMed]

82. Zhou, Z.; Tao, Y.; Zhao, H.; Wang, Q. Adipose Extracellular Vesicles, Messengers From and to Macrophages in Regulating Immunometabolic Homeostasis or Disorders. Front. Immunol. 2021, 12, 666344. [CrossRef]

83. Jin, J.; Shi, Y.; Gong, J.; Zhao, L.; Li, Y.; He, Q.; Huang, H. Exosome secreted from adipose-derived stem cells attenuates diabetic nephropathy by promoting autophagy flux and inhibiting apoptosis in podocyte. Stem Cell Res. Ther. 2019, 10, 95. [CrossRef] [PubMed]

84. Liu, W.; Yuan, Y.; Liu, D. Extracellular Vesicles from Adipose-Derived Stem Cells Promote Diabetic Wound Healing via the PI3K-AKT-mTOR-HIF-1 $\alpha$ Signaling Pathway. Tissue Eng. Regen. Med. 2021, 18, 1035-1044. [CrossRef] [PubMed]

85. Moore, T.; Beltran, L.; Carbajal, S.; Strom, S.; Traag, J.; Hursting, S.D.; Di Giovani, J. Dietary energy balance modulates signaling through the Akt/Mammalian Target of Rapamycin pathways in multiple epithelial tissues. Cancer Prev. Res. 2008, 1, 65-76. [CrossRef] [PubMed]

86. Jiang, W.; Zhu, Z.; Thompson, H.J. Dietary energy restriction modulates the activity of Akt and mTOR in mammary carcinomas, mammary gland, and liver. Cancer Res. 2008, 68, 5492-5499. [CrossRef]

87. Laplante, M.; Sabatini, D.M. mTOR signaling in growth control and disease. Cell 2012, 149, 274-293. [CrossRef] [PubMed]

88. Szwed, A.; Kim, E.; Jacinto, E. Regulation and metabolic functions of mTORC1 and mTORC2. Physiol. Rev. 2021, 101, 1371-1426. [CrossRef]

89. Bell, A.; Grunder, L.; Sorisky, A. Rapamycin inhibits human adipocyte differentiation in primary culture. Obes. Res. 2000, 8, 249-254. [CrossRef] [PubMed]

90. Fang, Y.; Westbrook, R.; Hill, C.; Boparai, R.K.; Arum, O.; Spong, A.; Wang, F.; Javors, M.A.; Chen, J.; Sun, L.Y.; et al. Duration of rapamycin treatment has differential effects on metabolism in mice. Cell Metab. 2013, 17, 456-462. [CrossRef]

91. Yang, F.; Du, L.; Song, G.; Zong, X.; Jin, X.; Yang, X.; Qi, Z. Rapamycin and 3-Methyladenine Influence the Apoptosis, Senescence, and Adipogenesis of Human Adipose-Derived Stem Cells by Promoting and Inhibiting Autophagy: An In Vitro and In Vivo Study. Aesthetic Plast. Surg. 2021, 45, 1294-1309. [CrossRef]

92. Wei, W.; Ao, Q.; Wang, X.; Cao, Y.; Liu, Y.; Zheng, S.G.; Tian, X. Mesenchymal Stem Cell-Derived Exosomes, A Promising Biological Tool in Nanomedicine. Front. Pharmacol. 2021, 11, 590470. [CrossRef] 
93. Constantin, A.; Filippi, A.; Alexandru, N.; Nemecz, M.; Georgescu, A. Extracellular Vesicles from Adipose Tissue Stem Cells in Diabetes and Associated Cardiovascular Disease; Pathobiological Impact and Therapeutic Potential. Int. J. Mol. Sci. 2020, $21,9598$. [CrossRef] [PubMed]

94. Storti, G.; Favi, E.; Albanesi, F.; Kim, B.S.; Cervelli, V. Adipose-Derived Stem/Stromal Cells in Kidney Transplantation: Status Quo and Future Perspectives. Int. J. Mol. Sci. 2021, 22, 11188. [CrossRef] [PubMed]

95. Abreu, H.; Canciani, E.; Raineri, D.; Cappellano, G.; Rimondini, L.; Chiocchetti, A. Extracellular Vesicles in Musculoskeletal Regeneration: Modulating the Therapy of the Future. Cells 2021, 11, 43. [CrossRef] [PubMed]

96. Zhang, Y.; Zhang, C.; Wang, J.; Liu, H.; Wang, M. Bone-Adipose Tissue Crosstalk: Role of Adipose Tissue Derived Extracellular Vesicles in Bone Diseases. J. Cell Physiol. 2021, 236, 7874-7886. [CrossRef]

97. Shukla, L.; Yuan, Y.; Shayan, R.; Greening, D.W.; Karnezis, T. Fat Therapeutics: The Clinical Capacity of Adipose-Derived Stem Cells and Exosomes for Human Disease and Tissue Regeneration. Front. Pharmacol. 2020, 11, 158. [CrossRef]

98. Jeyaram, A.; Jay, S.M. Preservation and Storage Stability of Extracellular Vesicles for Therapeutic Applications. AAPS J. 2017, 20, 1. [CrossRef]

99. Johnson, J.; Shojaee, M.; Mitchell Crow, J.; Khanabdali, R. From Mesenchymal Stromal Cells to Engineered Extracellular Vesicles: A New Therapeutic Paradigm. Front. Cell Dev. Biol. 2021, 9, 705676. [CrossRef]

100. Phinney, D.G.; Pittenger, M.F. Concise Review, MSC-Derived Exosomes for Cell-Free Therapy. Stem Cells 2017, 35, 851-858 [CrossRef]

101. Yin, Y.; Chen, H.; Wang, Y.; Zhang, L.; Wang, X. Roles of extracellular vesicles in the aging microenvironment and age-related diseases. J. Extracell. Vesicles 2021, 10, e12154. [CrossRef]

102. Harrison, M.A.A.; Wise, R.M.; Benjamin, B.P.; Hochreiner, E.M.; Mohiuddin, O.A.; Bunnell, B.A. Adipose-Derived Stem Cells from Obese Donors Polarize Macrophages and Microglia toward a Pro-Inflammatory Phenotype. Cells 2020, 10, 26. [CrossRef]

103. Qingguo, Z.; Carl, A.G.; Hwa, L.R.; Roxanne, L.R.; Lizheng, Q.; Bo, H.; Park, M.S.; Yoon, N.; Clough, B.; McNeill, E.; et al. MSCs derived from iPSCs with a modified protocol are tumor-tropic but have much less potential to promote tumors than bone marrow MSCs. Proc. Natl. Acad. Sci. USA 2015, 112, 530-535. [CrossRef]

104. Barkholt, L.; Flory, E.; Jekerle, V.; Lucas-Samuel, S.; Ahnert, P.; Bisset, L.; Büscher, D.; Fibbe, W.; Foussat, A.; Kwa, M.; et al. Risk of tumorigenicity in mesenchymal stromal cell-based therapies-bridging scientific observations and regulatory viewpoints. Cytotherapy 2013, 15, 753-759. [CrossRef] [PubMed]

105. Li, T.; Zhou, X.; Wang, J.; Liu, Z.; Han, S.; Wan, L.; Sun, X.; Chen, H. Adipose-derived mesenchymal stem cells and extracellular vesicles confer antitumor activity in preclinical treatment of breast cancer. Pharmacol. Res. 2020, 157, 104843. [CrossRef] [PubMed]

106. Storti, G.; Scioli, M.G.; Kim, B.S.; Terriaca, S.; Fiorelli, E.; Orlandi, A.; Cervelli, V. Mesenchymal Stem Cells in Adipose Tissue and Extracellular Vesicles in Ovarian Cancer Patients, A Bridge toward Metastatic Diffusion or a New Therapeutic Opportunity? Cells 2021, 10, 2117. [CrossRef] [PubMed]

107. Gonzalez, F.J.; Xie, C.; Jiang, C. The role of hypoxia-inducible factors in metabolic diseases. Nat. Rev. Endocrinol. 2018, 15, 21-32. [CrossRef]

108. Jung, J.S.; Volk, C.; Marga, C.; Navarrete Santos, A.; Jung, M.; Rujescu, D.; Navarrete Santos, A. Adipose-Derived Stem/Stromal Cells Recapitulate Aging Biomarkers and Show Reduced Stem Cell Plasticity Affecting Their Adipogenic Differentiation Capacity. Cell. Reprogram. 2019, 21, 187-199. [CrossRef]

109. Picca, A.; Guerra, F.; Calvani, R.; Bucci, C.; Lo Monaco, M.R.; Bentivoglio, A.R.; Coelho-Júnior, H.J.; Landi, F.; Bernabei, R.; Marzetti, E. Mitochondrial Dysfunction and Aging, Insights from the Analysis of Extracellular Vesicles. Int. J. Mol. Sci. 2019, 20, 805. [CrossRef]

110. Kwan, H.Y.; Chen, M.; Xu, K.; Chen, B. The impact of obesity on adipocyte-derived extracellular vesicles. Cell. Mol. Life Sci. 2021, 78, 7275-7288. [CrossRef]

111. Chabria, Y.; Duffy, G.P.; Lowery, A.J.; Dwyer, R.M. Hydrogels: 3D Drug Delivery Systems for Nanoparticles and Extracellular Vesicles. Biomedicines 2021, 9, 1694. [CrossRef]

112. Gowen, A.; Shahjin, F.; Chand, S.; Odegaard, K.E.; Yelamanchili, S.V. Mesenchymal stem cell-derived extracellular vesicles: Challenges in clinical applications. Front. Cell Dev. Biol. 2020, 8, 149. [CrossRef]

113. Gimona, M.; Pachler, K.; Laner-Plamberger, S.; Schallmoser, K.; Rohde, E. Manufacturing of human extracellular vesicle-based therapeutics for clinical use. Int. J. Mol. Sci. 2017, 18, 1190. [CrossRef] [PubMed] 